\title{
Effects of Administration of an Organo-phosphorus Compound as an Antibilharzial Agent, with Special Reference to Plasma Cholinesterase
}

\author{
SAMIR HANNA,* M.B., B.CH., PH.D. ; K. BASMY, $\dagger$ M.D. ; OSAIMA SELIM, $\ddagger$ M.B., B.CH. \\ S. M. SHOEB, $\S$ M.D.; A. Y. AWNY, $\|$ M.D., M.SC.
}

Brit. med. F., 1966, 1, 1390-1392

The organo-phosphorus compound Dipterex ${ }^{1}$ (trichlorphon; OO-dimethyl-2,2,2,-trichlorethyl phosphonate) has attracted considerable attention during the past few years. Besides its use as an insecticide, an attempt has been made to employ this substance for the treatment of intestinal parasites (Beheyt, Lebrun, Cerf, Dierickx, and Degroote, 1961 ; Cerf, Lebrun, and Dierickx, 1962).

Schistosomiasis is a very common condition in the United Arab Republic and a simplified course of treatment given by mouth would be a great improvement on the treatment in use. Hence a trial experiment was carried out to evaluate the efficacy of Dipterex in treating bilharziasis.

\section{Material}

Ten male patients suffering from active urinary bilharziasis were admitted to the Department of Endemic and Tropical Medicine, Ein Shams University Hospital, for the purpose of this study. All revealed living and hatchable Schistosoma haematobium ova in their urine. Their ages ranged from 16 to 28 years. Two had mild asthmatic bronchitis, six had moderate hepatosplenomegaly, and one had hepatomegaly alone. One patient was also suffering from intestinal bilharziasis and had living $S$. mansoni ova in the stools. One patient had both $S$. haematobium and $S$. mansoni ova in the urine.

Examination of the stools revealed Ancylostoma duodenale ova in six cases, Ascaris lumbricoides ova in three, Enterobius vermicularis in two, Hymenolepis nana in two, and Trichostrongylus stercoralis in one case.

Patients were subjected to thorough medical examination before, during, and after treatment. Besides plasma cholinesterase, laboratory studies included the blood picture, blood urea, plasma proteins, serum transaminases, serum alkaline phosphatase, and seminal fluid.

Dipterex was given in a dose of $5 \mathrm{mg}$. $/ \mathrm{kg}$. body-weight once daily, in the morning, for 12 consecutive days, and, because of attacks of colic, atropine sulphate, $1 \mathrm{mg}$. three times a day, was administered orally.

Samples of blood for laboratory examination were collected in dry heparinized tubes, and the plasma was at once separated. Determinations of enzymes were carried out on the same day. For determination of cholinesterase, samples were collected on two consecutive days before starting treatment. On the first day of treatment samples were taken 30 minutes, one hour, and two hours after the ingestion of Dipterex. On the eighth day of treatment one sample was taken before ingestion of the drug. Samples were also collected three days after the last dose was

* Lecturer in Chemical Pathology, Ein Shams University, Cairo. † Lecturer in Tropical Medicine, Ein Shams University. $\ddagger$ Demonstrator turer in Tropical Medicine, Ein Shams University. Assistant Professor in Chemical Pathology, Ein Shams University. Assistant Professor in Tropical Medicine, Ein Shams

Also called: Bayer L 13/59, Bayer 2349 ; or Dylox (Bayer, Leverkusen, West Germany). given. Samples of seminal fluid were collected by masturbation before treatment and on the day after the end of the course.

\section{Methods}

Plasma Cholinesterase.-For various reasons (see Results and Discussion) the method described by Molander, Friedman, and La Due (1954) was used, with some modifications. This method depends upon the colorimetric determination of changes in $p \mathrm{H}$ produced by the liberation of acetic acid as a result of hydrolysis of acetylcholine.

The original method may be summarized as follows:

Reagents.-(1) Barbiturate buffer, stock. Dissolve $10.3 \mathrm{~g}$. sodium barbitone in $500 \mathrm{ml}$. water. (2) $0.1 \mathrm{~N} \mathrm{HCl}$. (3) Indicator. Dissolve $0.05 \mathrm{~g}$. phenol red in $10 \mathrm{ml}$. $0.1 \mathrm{~N} \mathrm{NaOH}$ and dilute to $200 \mathrm{ml}$. with water. (4) Substrate. Dissolve $3.5 \mathrm{~g}$. acetylcholine chloride in $100 \mathrm{ml}$. water.

Procedure-(1) To each of three tubes add $2 \mathrm{ml}$. barbiturate buffer, $p \mathrm{H} 8.4$, prepared by mixing $8.23 \mathrm{ml}$. stock buffer with 1.77 ml. $0.1 \mathrm{~N} \mathrm{HCl}$. (2) To the sample tube add $1 \mathrm{ml}$. substrate and $0.1 \mathrm{ml}$. serum. (3) To each of the other two tubes add $1 \mathrm{ml}$. water and $0.1 \mathrm{ml}$. serum. (4) Incubate all tubes at $37^{\circ} \mathrm{C}$. for two hours. (5) Add $7 \mathrm{ml}$. water to each tube. (6) Add $0.15 \mathrm{ml}$. indicator to the sample tube and to one of the blank tubes. (7) Using the blank without indicator to set the instrument, read the sample and the blank at $535 \mathrm{~m}^{\prime \prime}$. (8) Calculate $\mathrm{pH}$ from a curve showing optical density at different levels of $p \mathrm{H}$.

Modifications Introduced.-(a) Instead of adding each buffer and substrate alone before incubation and adding the dye after incubation a mixture of all three reagents was prepared daily from separate stock solutions. An automatic burette was used to deliver aliquots of $3 \mathrm{ml}$. into the required number of test-tubes. (b) Instead of acetylcholine chloride-a very deliquescent substance-acetylcholine bromide was used. (c) In the original method a blank was prepared for each sample of plasma with $1 \mathrm{ml}$. of water instead of the substrate. It is shown below that the acetylcholine chloride solution per se produces marked changes in the $p \mathrm{H}$ of the buffer solution. It is therefore both useless and tedious to prepare a blank for every sample of plasma ; $0.1 \mathrm{ml}$. of plasma will hardly produce any change in the optical density or $\mathrm{pH}$ of the barbiturate buffer. Hence one "reagent blank" was prepared by adding all reagents except plasma for each batch of tests.

The effects of these modifications on the test are discussed under "Results and Discussion."

In-vitro Experiment.-An in-vitro experiment was carried out to test the effect of Dipterex on cholinesterase. Random samples of plasma were used. Plasma cholinesterase was determined on each of the samples with and without the addition of $0.1 \mathrm{ml}$. of water containing a known amount of Dipterex.

Serum Transaminases. - The methods described by King and Wootton (1956) were used for the determination of serum glutamic oxaloacetic and glutamic pyruvic transaminases.

Statistical Methods. - The standard deviation, standard error of the mean, tests of significance, correlation coefficient, and regression were all performed, the methods reported by Snedecor (1956) being used. 


\section{Results and Discussion}

The results are summarized in Tables $\mathrm{I}-\mathrm{V}$ and the more striking findings are illustrated in Figs. 1-3.

\begin{tabular}{|c|c|c|c|c|c|c|c|c|}
\hline \multicolumn{5}{|c|}{ TABLE } & \multicolumn{2}{|c|}{ tients Receiving } & \multicolumn{2}{|l|}{ Dipterex } \\
\hline $\begin{array}{l}\text { Case } \\
\text { No. }\end{array}$ & Colic & Tremors & $\begin{array}{l}\text { Vomit- } \\
\text { ing }\end{array}$ & $\begin{array}{l}\text { Head- } \\
\text { ache }\end{array}$ & $\begin{array}{c}\text { Fall in } \\
\text { Syst. B.P. } \\
\text { below } \\
100\end{array}$ & $\begin{array}{l}\text { Faint- } \\
\text { ing } \\
\text { Sensa- } \\
\text { tion }\end{array}$ & $\begin{array}{c}\text { Pain in } \\
\text { Eyes. } \\
\text { Blurring } \\
\text { of Vision }\end{array}$ & $\begin{array}{l}\text { Retro- } \\
\text { sternal } \\
\text { Pain }\end{array}$ \\
\hline 1 & + & - & - & + & - & - & + & - \\
\hline 3 & ++ & $\bar{t}$ & $\overline{+}$ & \pm & $\bar{t}$ & $+\overline{+}+$ & $\begin{array}{l}+ \\
+\end{array}$ & $\overline{-}$ \\
\hline $\begin{array}{l}4 \\
5\end{array}$ & $\stackrel{+}{+}$ & $\overline{-}$ & $+\overline{+}+$ & $\overline{-}$ & $\overline{-}$ & $\bar{z}$ & $\begin{array}{l}+ \\
+\end{array}$ & $\overline{+}+$ \\
\hline 6 & + & - & + & - & + & + & - & - \\
\hline 8 & \pm & $\bar{z}$ & $\overline{-}$ & $\begin{array}{l}+ \\
+ \\
+\end{array}$ & \pm & \pm & \pm & \pm \\
\hline $\begin{array}{r}9 \\
10\end{array}$ & $\bar{t}$ & \pm & $\bar{z}$ & $\bar{z}$ & \pm & \pm & $\overline{-}$ & $\overline{-}$ \\
\hline
\end{tabular}

$+=$ Present. $+++=$ Present and severe. $-=$ Absent.

TABLE II.-Examination of Urine of Patients for Bilharzia Ova After

\begin{tabular}{|c|c|c|c|c|c|c|c|c|c|c|}
\hline $\begin{array}{l}\text { Days after } \\
\text { Treatment }\end{array}$ & Case & $\underset{2}{\text { Case }}$ & $\underset{3}{\text { Case }}$ & Case & $\underset{5}{\text { Case }}$ & $\begin{array}{c}\text { Case } \\
6\end{array}$ & $\begin{array}{c}\text { Case } \\
7\end{array}$ & $\underset{8}{\text { Case }}$ & $\underset{9}{\text { Case }}$ & $\begin{array}{c}\text { Case } \\
10\end{array}$ \\
\hline $\begin{array}{r}1 \\
30 \\
55 \\
60 \\
75 \\
122 \\
135\end{array}$ & $\begin{array}{l}\text { D } \\
- \\
-\end{array}$ & $\mathrm{D}$ & $\begin{array}{l}\mathrm{D} \\
\overrightarrow{\mathrm{D}}\end{array}$ & $\mathrm{D}$ & $\frac{\frac{D}{D}}{\frac{D}{D}}$ & $\begin{array}{c}\text { L.H. } \\
\bar{D} \\
D \\
\bar{D} \\
D \\
D\end{array}$ & $\mathrm{D}$ & $\begin{array}{c}\mathrm{D} \\
\underline{\mathrm{D}} \\
- \\
\text { L.H.H. }\end{array}$ & $\overline{-}$ & $\begin{array}{l}\text { D } \\
\frac{7}{-}\end{array}$ \\
\hline
\end{tabular}

L.H. $=$ Living and hatchable. $\quad \mathrm{D}=$ Dead ova. $\quad-=$ Urine negative for ova.

TABLE III.-Effect of Adding all Reagents for Plasma Cholinesterase Determination in One Lot Before Incubation (Multiple Analyses of One Sample of Plasma)

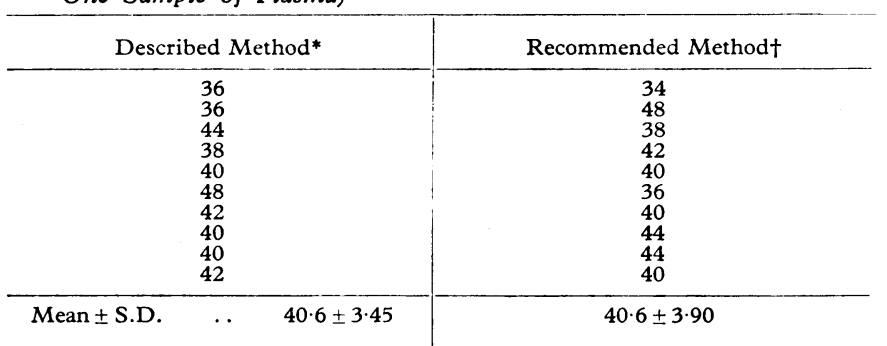

* Buffer and substrate were added separately; dye was added after incubation. † Buffer, substrate, and dye were all added before incubation.

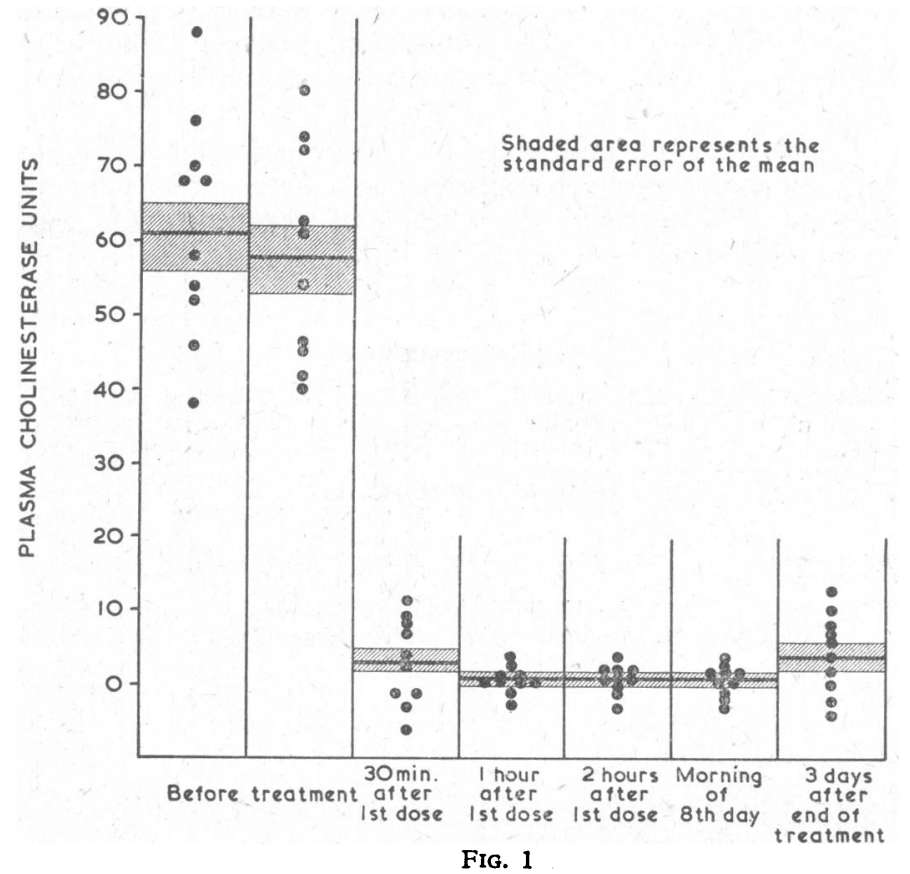

Table IV.-Changes in pH of Barbiturate Buffer Produced by Addition

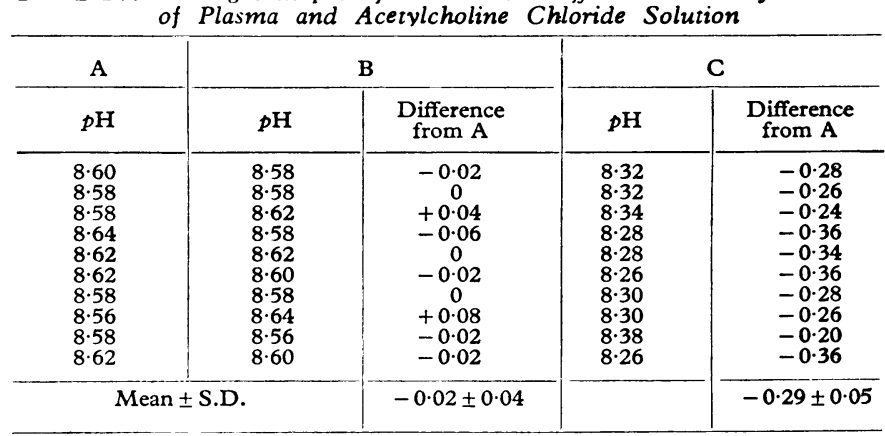

A: $2 \mathrm{ml}$. barbiturate buffer $+1 \mathrm{ml}$. water

B: $2 \mathrm{ml}$. barbicurace buffer $+1 \mathrm{ml}$. water $+0.1 \mathrm{ml}$. plasma.

C: $2 \mathrm{ml}$. barbiturate buffer $+1 \mathrm{ml}$. acetylcholine chloride solution.

TABLE V.-Effect of Treatment with Dipterex on Plasma Cholinesterase and Serum Transaminase.

\begin{tabular}{|c|c|c|c|c|c|c|c|c|c|c|c|}
\hline \multirow{3}{*}{$\begin{array}{l}\text { Case } \\
\text { No. }\end{array}$} & \multicolumn{4}{|c|}{ Serum Transaminases } & & & & & & & \\
\hline & \multicolumn{2}{|c|}{$\begin{array}{c}\text { Before } \\
\text { Dipterex }\end{array}$} & \multicolumn{2}{|c|}{$\begin{array}{c}\text { After } \\
\text { Dipterex }\end{array}$} & \multicolumn{7}{|c|}{ Cholinesterase } \\
\hline & $\begin{array}{c}\text { Pyru- } \\
\text { vic }\end{array}$ & $\begin{array}{l}\text { Oxalo- } \\
\text { acetic }\end{array}$ & $\begin{array}{c}\text { Pyru- } \\
\text { vic }\end{array}$ & Oxalo- & A & A & B & C & D & E & F \\
\hline $\begin{array}{r}1 \\
2 \\
3 \\
4 \\
5 \\
6 \\
7 \\
8 \\
9 \\
10\end{array}$ & $\begin{array}{r}18 \\
47 \\
12 \\
80 \\
20 \\
160 \\
59 \\
19 \\
37 \\
20\end{array}$ & $\begin{array}{r}25 \\
35 \\
26 \\
43 \\
25 \\
100 \\
90 \\
18 \\
23 \\
37\end{array}$ & $\begin{array}{r}2 \\
55 \\
18 \\
98 \\
20 \\
180 \\
62 \\
15 \\
22 \\
38\end{array}$ & $\begin{array}{r}30 \\
18 \\
38 \\
36 \\
31 \\
125 \\
32 \\
26 \\
30 \\
21\end{array}$ & $\begin{array}{l}52 \\
46 \\
68 \\
76 \\
88 \\
58 \\
38 \\
54 \\
70 \\
58\end{array}$ & $\begin{array}{l}54 \\
42 \\
72 \\
74 \\
52 \\
45 \\
40 \\
46 \\
80 \\
61\end{array}$ & $\begin{array}{r}4 \\
2 \\
-6 \\
11 \\
-1 \\
8 \\
7 \\
-3 \\
-1 \\
9\end{array}$ & $\begin{array}{r}2 \\
4 \\
1 \\
-3 \\
-1 \\
1 \\
3 \\
2 \\
1 \\
1\end{array}$ & $\begin{array}{r}4 \\
-3 \\
1 \\
2 \\
2 \\
1 \\
0 \\
2 \\
-1 \\
1\end{array}$ & $\begin{array}{r}1 \\
3 \\
2 \\
-2 \\
-2 \\
-3 \\
4 \\
1 \\
-1 \\
2\end{array}$ & $\begin{array}{r}8 \\
6 \\
0 \\
7 \\
-1 \\
-2 \\
-4 \\
13 \\
10 \\
2\end{array}$ \\
\hline an & $\begin{array}{l}47 \cdot 2 \\
14 \cdot 5\end{array}$ & $\begin{array}{r}42 \cdot 4 \\
9 \cdot 1\end{array}$ & $\begin{array}{l}49 \cdot 0 \\
20 \cdot 3\end{array}$ & $\begin{array}{r}38.7 \\
9.8\end{array}$ & $\begin{array}{r}60 \cdot 8 \\
4.5\end{array}$ & $\begin{array}{r}57 \cdot 6 \\
4 \cdot 5\end{array}$ & $\begin{array}{l}3.0 \\
1.7\end{array}$ & $\begin{array}{l}1.1 \\
0.6\end{array}$ & $\begin{array}{l}0.9 \\
0.6\end{array}$ & $\begin{array}{l}0.9 \\
0.7\end{array}$ & $\begin{array}{l}3.9 \\
1.8\end{array}$ \\
\hline
\end{tabular}

A: Before treatment.

B: Half an hour after ingestion of first dose.

C: One hour after ingestion of first dose.

E: On morning of 8 th day before ingestion of drug.

F: Three days after end of treatment.<smiles>COP(=O)(OC)C(O)C(Cl)(Cl)Cl</smiles><smiles>C[N+](C)(C)O</smiles>

DIPTEREX $\mathrm{C}_{4} \mathrm{H}_{8} \mathrm{O}_{4} \mathrm{Cl}_{3} \mathrm{P}$

CHOLINE

Fig. 3 -

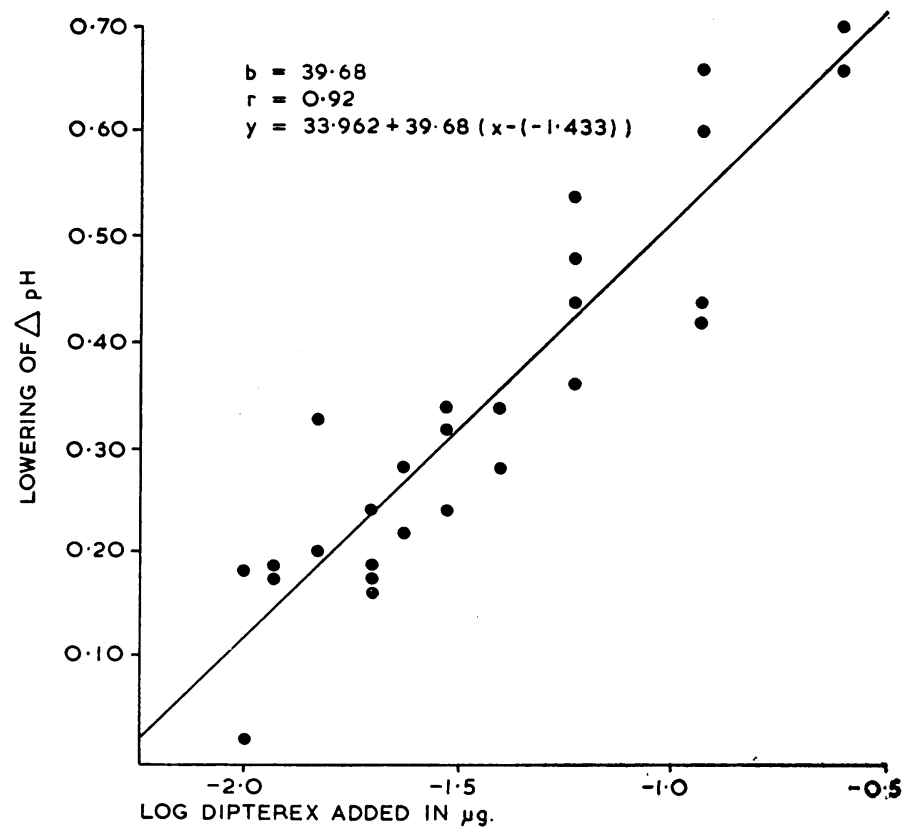

FIG. 2

Fig. 1.-Effect of ingestion of Dipterex on plasma cholinesterase. FIG. 2.-In vitro effect of adding Dipterex on plasma cholinesterase. 


\section{Clinical Evaluation}

Side-effects. - A summary of side-effects is presented in Table I. All side-effects were easily overcome. Most of these appeared in the middle of the day, after routine morning activities (toilet, etc.), and disappeared with confinement to bed. Their incidence increased with the progress of treatment until the third day, when they remained stationary.

Antibilharzial Effect.-The results of urine examination are given in Table II. One day after finishing the course of treatment-that is, on the thirteenth day-examination of urine revealed dead ova in nine cases, while one case showed living hatchable ova. This last case was cured 12 days later-on the twenty-fifth day. Six of the cases were followed up for 60 days after the end of treatment and four for 135 days. One of the latter cases showed living ova which contained a well-defined and moving miracidium. The mansoni ova which were present in the urine in one case (urinary mansoniasis) were dead three days after treatment, but those in stools were not affected.

Other Parasites.-In six cases of $A$. duodenale infestation the drug had no effect. The two cases of $H$. nana infestation were resistant to treatment. Among the three cases of ascariasis ova disappeared only in one.

\section{Plasma Cholinesterase}

Modification in Method.-The mean plasma cholinesterase level in healthy Egyptians is 59.5 units and in uncomplicated bilharzial patients 60.75 units ; the difference is not significant. The addition of all reagents (substrate, buffer, and dye) in one lot to the plasma before incubation did not significantly affect the resulk of plasma cholinesterase determination (Table III). Table IV shows the inherent error in using the blank recommended by Molander et al. (1954). Because of the adoption of this blank, some authors ( $\mathrm{S}$. Talaat, personal communication, 1964) failed to detect the marked effect (see below) of Dipterex on plasma cholinesterase. With the use of this blank the "zero" value of plasma cholinesterase will read up to 36 units.

Effect on Cholinesterase.-Table V summarizes the effect of the described dosage of Dipterex on plasma cholinesterase and serum transaminases. The effect on plasma cholinesterase (Fig. 1) started as early as 30 minutes after the oral ingestion of the first dose and lasted throughout the course and for at least three days after the end of the treatment. A few scattered results, not included in our tables or figures, show that the effect may last up to a fortnight after the end of the treatment. In Fig. 2 the in-vitro effect of Dipterex is shown. A strong correlation exists between the log dose of Dipterex added and the inhibition of plasma cholinesterase. From the in-vitro experiment one can calculate that at a plasma level of $0.4 \mathrm{mg} . / 100 \mathrm{ml}$. Dipterex will depress plasma cholinsterase by $50 \%$, and at 2 mg. $/ 100 \mathrm{ml}$. plasma cholinesterase will almost reach zero. In view of the relative absence of daily variations in plasma cholinesterase levels (Kaufman, 1954), testing of subjects exposed to organo-phosphorus compounds, before and after exposure, might help to evaluate roughly the plasma level of some of those compounds. The nature of the inhibition is not very well understood. However, phosphorus and nitrogen are both near neighbours in the periodic table of elements (group Vb). A similarity between the structure of choline and Dipterex (Fig. 3) can be claimed in competitive inhibition may be postulated.

\section{Effect on Seminal Fluid}

The spermatic count and volume of seminal fluid before and after exposure to Dipterex were investigated in nine subjects. Reduction in the count was observed in all nine, and the volume of fluid was also reduced in eight. A follow-up showed in some cases that the spermatic count returned slowly to the original levels and in one case increased beyond that.

The effect on the motility and viability of the sperms was also as striking as the effect on the counts. In all nine cases a marked decrease in motility and viability was observed.

There was also a definite increase in the number of abnormal forms. Before treatment the abnormal forms did not account for more than $20 \%$ in all patients except Nos. 7 and 8 , who had $28 \%$ and $32 \%$ respectively of abnormal sperms. These increased to $46 \%$ and $55 \%$ at the end of the course of treatment. In the other cases the abnormal forms accounted for 30 to $48 \%$ of the observed sperms. The anomalies included cytoplasmic masses (which are evidence of immaturity), pinheads, rounded heads, and double heads. Tail anomalies were also observed; these included double tails or coiled tails, and absence of tails.

Other Laboratory Findings.-There was no change in the serum transaminases (Table V). The white-cell count and haemoglobin percentage did not show any significant change; nor did all other laboratory tests.

\section{Summary}

Ten cases of urinary bilharziasis were treated with Dipterex (trichlorphon) and the results of treatment and follow-up are presented.

Side-effects, such as vomiting, colic, fainting sensation, actual fainting, retrosternal pain, blurring of vision, bronchial spasm, headache, and tremors, were observed. In spite of these sideeffects, all patients were able to complete the course of treatment.

Dipterex depresses the plasma cholinesterase dramatically. The depression starts as early as 30 minutes after oral ingestion of the first dose and lasts until at least three days after the end of treatment.

Serum glutamic oxaloacetic and glutamic pyruvic transaminases were not affected by this single course of treatment. The leucocyte count, haemoglobin, urea clearance, and electrocardiogram did not show important changes. The drug lowered both the number and the percentage motility of sperms in some of the cases.

In the described dosage the drug does not seem to have a lasting curative effect on schistosomiasis, since recurrences are frequent. Variations on the schedule of treatment might help to suppress these recurrences.

\section{REFERENCES}

Beheyt, P., Lebrun, A.. Cerf, J., Dierickx, J., and Degroote, V. (1961). Beheyt, P., Lebrun, A.. Cerf, Hlth Org., 24, 465.

Cerf, J., Lebrun, A., and Dierickx, J. (1962). Amer. F. trop. Med. Hyg., $11,514$.

Kaufman, K. (1954). Ann. intern. Med., 41, 533.

King, E. J., and Wootton, I D. P. (1956). Micro-analysis in Medical Bioc hemistry, 3rd ed. Churchili, London.

Molander, D. W., Friedman. M. M., and La Due, J. S. (1954). Ann. intern. Med., 41, 1139.

Snedecor, G. W. (1956). Statistical Methods Applied to Experiments in Agriculture and Biology, 5th ed. Iowa State College Press, Ames, Iowa. 